\title{
Response of Maize to Integrated Nitrogen Management and Its Application Time
}

\section{${ }^{1}$ Talha Jan, ${ }^{1 *}$ Nangial Khan, ${ }^{1}$ Farooq Nawaz, ${ }^{1}$ Mehran Ali, ${ }^{1}$ Salman Ali and ${ }^{1}$ Junaid Ahmad}

${ }^{1}$ Department of Agronomy, The University of Agriculture Peshawar, Pakistan.

Correspondence Author: Nangial Khan, Department of Agronomy, The University of Agriculture Peshawar, Pakistan. E-mail: nangialkhan@hotmail.com

Received date: 10 January 2018, Accepted date: 28 February 2018, Online date: 10 March 2018

Copyright: (C) 2018 Talha Jan et al. This is an open-access article distributed under the terms of the Creative Commons Attribution License, which permits unrestricted use, distribution, and reproduction in any medium, provided the original author and source are credited.

\begin{abstract}
Integrated nitrogen management and its application at suitable time is critical for increased soil productivity and crop sustainability. The objective of the current study was to evaluate the effect of crop residues, its application time and suitable application stage for nitrogen fertilization on yield of maize (Zea may L.) The experiment was conducted during summer 2014and experimental design was randomized complete block (RCB) design having four replications. Cereal and legume residues at the rate of $5 \mathrm{t} \mathrm{ha}^{-1}$ each were applied at three different stages, i.e. 15 days before sowing, 7 days before sowing and at sowing while fertilizer nitrogen was applied at the rate of $100 \mathrm{~kg} \mathrm{ha}^{-1}$ in full and split doses at various growth stages (sowing and V6 stages). The results showed that legume residues resulted in higher grains ear-1 (298), 1000 grains weight (204 g) and grain yield (2290 kg ha-1). Among nitrogen application stages, split application resulted in maximum ears plant ${ }^{-1}$ (0.87), grains ear-1 $1000 \mathrm{GW}$ (208 g), stover yield (8269 kg ha-1) and grain yield (2414 kg ha-1). Results presented that cereal residues and full dose of nitrogen at any stage performed poorly and resulted in least values of these parameters. It is concluded that legume residues at the rate of $5 \mathrm{t} \mathrm{ha}^{-1}$ along with the split application of nitrogen at the rate of $120 \mathrm{~kg}^{-1}$ maximized the productivity of maize.
\end{abstract}

Key words: Maize, Integrated Nitrogen Management, Application Timing

\section{INTRODUCTION}

Maize (Zea mays L.) is world's third most important cereal crop after wheat and rice both in area and production. It has the highest production potential among cereal crops [1]. Maize has a high soil fertility requirement to achieve high yields and thus large quantities of nitrogen are required [2]. Organic sources of nitrogen are known to supply micro and macro nutrients for crop use. They contribute directly to the building of soil organic matter, which perform significant role in improving soil chemical, physical and biological properties [3]. Studies have shown the superior effect of integrated nitrogen management over sole use of inorganic or organic source in terms of improved soil fertility, balanced nutrient supply, and crop yield [4]. Several researchers [4,5] reported that the integrated use of mineral and organic $\mathrm{N}$ sources play key role in getting sustainability in agriculture. They reported that integrated nitrogen management play vital role for improving maize biological yield and grain yield. It can result in positive economic returns and at the same time limiting negative environmental impacts of crop production [6]. This shows that neither alone organic nor inorganic source is panacea for soil fertility management.

The fertilizer use efficiency is mostly affect by timing of fertilizers application. To synchronize the nutrients supply with plant, demand the nutrients leaching is reduce [7]. Split-application of fertilizer is an essential approach to increase the nitrogen use efficiency in maize [1]. It improves nitrogen use by the crop while reducing the nutrient loss through leaching and volatilization [8]. [9] reported greater uptake of nitrogen, grain yield, heavier grains and it also promoted the crop growth than full application. [10] found that split applications increased the grain yield from 2.7 to $4.5 \mathrm{t}$ ha ${ }^{-1}$. The research work was carried out to find the response of response of maize to integrated nitrogen management and its application time.

\section{MATERIALS AND METHODS}

Experiment was conducted at Agronomy Research Farm at The University of Agriculture, Peshawar during summer 2014. The experiment was laid out in Randomized Complete Block design with four replications. Maize variety Azam was sown on 18 th June 2014 . Each plot of size 3 m x $3.5 \mathrm{~m}$ had five rows with R$\mathrm{R} 75 \mathrm{~cm}$.

Experimental Site:

The experimental site is located in Peshawar at $34^{\circ} \mathrm{N}, 71.3^{\circ} \mathrm{E}$ and an altitude of 450 meters above sea level. The soil of the experimental site is silty clay loam, low in organic matter $(0.7-0.9 \%)$ low in nitrogen $(0.03-0.04 \%)$ and alkaline in reaction $(\mathrm{pH} 8.0-8.2)$ [11].

Table 1: Factors and their levels

\begin{tabular}{|l|l|}
\hline Factors & Levels \\
\hline Residues & Cereal \\
\cline { 2 - 2 } & Legume \\
\hline Residues application time & 0 Days before sowing \\
\hline
\end{tabular}


Citation: Talha Jan, Nangial Khan, Farooq Nawaz, Mehran Ali, Salman Ali and Junaid Ahmad, 2018. Response Of Maize To Integrated Nitrogen Management And Its Application Time. Advances in Environmental Biology., 12(2): 17-19.

Nitrogen application stage

7 Days before sowing

15 Days before sowing

S1 (full at sowing)

S2 (full at V6 stage)

Half at $\mathrm{S} 1+$ half at $\mathrm{S} 2$

Statistical analysis:

The data were statistically analyzed using analysis of variance technique appropriate for randomized complete block design. Means were compared using Least Significant Difference (LSD) test at 0.05 level of probability, when the F-values were significant [12].

\section{RESULTS AND DISCUSSION}

The results obtained on the effect of integrated use of urea and compost on yield and $\mathrm{N}$ uptake of maize are presented and discussed below:

Grains ears $^{-1}$ :

The results showed that crop residues and nitrogen application stages significantly $(\mathrm{P}<0.05)$ affected the grains ears ${ }^{-1}$ of maize. The maximum grains ears ${ }^{1}(298)$ was obtained from legume treated plots as compared to minimum grains ears ${ }^{-1}(270)$ obtained in treatments receiving cereal residues. Among nitrogen application stages, nitrogen applied in two splits i.e. half at sowing and half at V6 stage produced higher grains ears ${ }^{-1}(307)$ while plots treated with nitrogen applied as full dose at V6 stage produced lower grains ears ${ }^{-1}(264)$. Residue application time, control vs rest and all interactive responses were found non-significant. Our results aresupported by the findings of [13] and [14] who reported that combined use of urea and organic manure significantly increased grains ear ${ }^{-1}$ of maize.

\section{Ears plant ${ }^{-1}$ :}

Analysis of data showed that crop residues and nitrogen application stages significantly influenced tears plant ${ }^{-1}$ of maize. Maximum ears plant $^{-1}$ of 0.86 were obtained in treatment receiving cereal residues as compares to minimum ears plant ${ }^{-1}$ of 0.80 obtained in treatments receiving legume residues. Among nitrogen application stages, nitrogen applied in two splits i.e. half at sowing and half at V6 stage produced higher ears plant ${ }^{-1}(0.87)$ while plots treated with nitrogen applied as full dose at V6 stage resulted in lower ears plant ${ }^{-1}$ of 0.80 . Our results are in similarity with [13] who reported higher number of ears plant ${ }^{-1}$ when nitrogen was applied in organic and inorganic combination. However, our results are in contrast with the findings of [14] who reported that combined use of urea and organic manure had no significant effect on ears plants ${ }^{-1}$.

Table 2: Yield and yield components of maize as affected by integrated nitrogen management and application.

\begin{tabular}{|c|c|c|c|c|c|c|}
\hline Factors & $\begin{array}{c}\text { Ears } \\
\text { plant }^{-1}\end{array}$ & $\begin{array}{c}\text { Grains } \\
\text { ear }^{-1}\end{array}$ & $\begin{array}{l}1000 \text { grains } \\
\text { Weight }(\mathrm{g})\end{array}$ & Plants at harvest & $\begin{array}{c}\text { Stover yield } \\
(\mathrm{kg} / \mathrm{ha})\end{array}$ & $\begin{array}{c}\text { Grain yield } \\
(\mathrm{kg} / \mathrm{ha})\end{array}$ \\
\hline \multicolumn{7}{|l|}{ Residues } \\
\hline Cereal & $0.86 \mathrm{a}$ & $270 \mathrm{~b}$ & $187 \mathrm{~b}$ & 51543 & 7903 & $2011 \mathrm{~b}$ \\
\hline Legume & $0.80 \mathrm{~b}$ & $298 \mathrm{a}$ & $204 \mathrm{a}$ & 52654 & 7363 & $2290 \mathrm{a}$ \\
\hline LSD & 0.05 & 24.6 & 14.61 & $\mathrm{~ns}$ & Ns & 262.66 \\
\hline \multicolumn{7}{|c|}{ Residues application time } \\
\hline 0 Days before sowing & 0.81 & 285 & 191 & 49907 & 7597 & 2027 \\
\hline 7 Days before sowing & 0.83 & 285 & 193 & 53426 & 7881 & 2241 \\
\hline 15 Days before sowing & 0.84 & 282 & 202 & 52963 & 7421 & 2183 \\
\hline LSD & Ns & Ns & Ns & $\mathrm{ns}$ & Ns & Ns \\
\hline \multicolumn{7}{|c|}{ Nitrogen application stage } \\
\hline S1 (full at sowing) & $0.81 \mathrm{~b}$ & $281 \mathrm{ab}$ & $193 \mathrm{bc}$ & 53796 & $7315 \mathrm{~b}$ & $2065 \mathrm{~b}$ \\
\hline S2 (full at V6 stage) & $0.80 \mathrm{bc}$ & $264 \mathrm{~b}$ & $185 \mathrm{~b}$ & 53888 & $7315 \mathrm{~b}$ & $1972 \mathrm{bc}$ \\
\hline Half at $\mathrm{S} 1+$ half at $\mathrm{S} 2$ & $0.87 \mathrm{a}$ & $307 \mathrm{a}$ & $208 \mathrm{a}$ & 49907 & $8269 \mathrm{a}$ & $2414 \mathrm{a}$ \\
\hline LSD & Ns & 30.12 & 17.89 & Ns & 817.61 & 321.69 \\
\hline Control & $0.76 \mathrm{~b}$ & $266.75 b$ & $164 \mathrm{~b}$ & $64444 \mathrm{~b}$ & $6136 b$ & $1648 b$ \\
\hline Rest & $0.83 a$ & $284.14 \mathrm{a}$ & $195 \mathrm{a}$ & $52099 \mathrm{a}$ & $7633 \mathrm{a}$ & $2150 \mathrm{a}$ \\
\hline
\end{tabular}

Mean values followed by different letters in each category are significantly different at 5\% level of probability using LSD test.

ns $=$ Non-significant

1000 grains weight:

The results showed that crop residues and nitrogen application stages significantly affected the 1000 grains weight of maize. Higher 1000 grains weight (204 gm) was obtained in treatment receiving legume residues as compares to minimum 1000 grains weight (187 gm) obtained in treatments having cereal residues. Split application of nitrogen resulted in higher 1000 grains weight (208 gm) while plots treated with nitrogen applied as full dose at V6 stage produced lower 1000 grains weight (185 gm). Similar results were found by [13] who reported that higher thousand grains weight of maize was obtained when nitrogen from inorganic fertilizer and organic fertilizer each were applied in combination. Our results are also in line with the finding of [15] who concluded that 1000 grain weight was significantly affected by the application time of fertilizer at different growth stages of maize crop. Similar results were also found by [13] who reported that higher thousand grains weight of maize was obtained when nitrogen from inorganic fertilizer and organic fertilizer each were applied in combination.

\section{Plants at harvest:}

Analysis of the data proved that control vs rest significantly influenced the plants at harvest of maize. Higher plants at harvest (64444) were recorded in the rest plots compared to lower plants at harvest (52099) recorded in control plots. Crop residues, nitrogen application stages and residue application time and all interactive responses were found non-significant.

Stover yield:

The results showed that nitrogen application stages significantly affected the stover yield of maize. Nitrogen applied in two splits i.e. half at sowing and half at V6 stage produced higher stover yield $\left(8269 \mathrm{~kg} \mathrm{ha}^{-1}\right)$ while plots treated with nitrogen applied as full dose at sowing and V6 stage produced lower stover yield of $7315 \mathrm{~kg} \mathrm{ha}^{-1}$. Control vs rest also showed significant results. Maximum 1000 stover yield $\left(7633 \mathrm{~kg}^{-1}\right)$ was recorded in the rest plots compared to lower stover yield $\left(6136 \mathrm{~kg} \mathrm{ha}^{-1}\right)$ recorded in control plots. Crop residues, residue application time and all interactive responses were found non-significant. These results are in line with the findings of [11] who reported highest biomass yield of maize with split application of nitrogen.

\section{Grain yield:}

The results showed that crop residues and nitrogen application stages significantly $(\mathrm{P}<0.05)$ affected the grain yield of maize. The maximum grain yield of

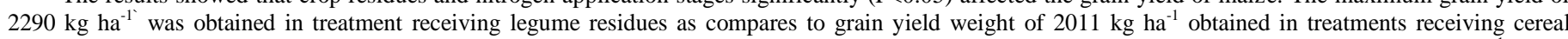
residues. Among nitrogen application stages, nitrogen applied in two splits i.e. half at sowing and half at V6 stage produced higher grain yield (2414 kg ha ${ }^{-1}$ ) while plots treated with nitrogen applied as full dose at V6 stage produced lower grain yield of $1972 \mathrm{~kg} \mathrm{ha}^{-1}$. Residue application time and all interactive responses 
except residue x NAS were found non-significant. Similar results were found by [16] who suggested that grain yield of maize can be multiplied by applying organic manure in combination with urea.

Conclusion and Recommendation:

Legume residues and application of nitrogen fertilizer in two splits i.e. half at sowing and half at V6 stage performed better in terms of maize productivity. Thus application of legume residues with $120 \mathrm{~kg} \mathrm{~N} \mathrm{ha}^{-1}$ in two splits i.e. half at sowing and half at $\mathrm{V} 6$ stage is recommended for higher maize productivity.

\section{ACKNOWLEDGEMENT}

The author is greatly grateful to The University of Agriculture Peshawar- for their support, friendly approach and using their resources.

Authors Contribution:

Talha Jan, Nangial Khan and Mehran Ali played their important role and assisted this field study both in field as well as in lab, and were involved in treatments application. Farooq Nawaz and Salman Ali assisted this study in experimental data collection and analysis. Talha Jan, Nangial Khan and Junaid Ahmad played there crucial role in analysis and parameters data collection.

\section{REFERENCES}

[1] Muthukumar, V.B., K. Velayudham and N. Thavaprakaash, 2007. Plant growth regulators and split application of nitrogen improves the quality parameters and green ear yield of baby corn. J. Agron., 6(1): 2008-211.

[2] Uribelarrea, M., S.J.C. Brandner and F.E. Below, 2009. Physiological N response of field-grown maize hybrids with divergent yield potential and grain protein concentration. Plant Soil. J., 316: 151-160.

[3] Gruhn, P., F. Golleti and M. Yudelman, 2000. Integrated nutrient management, soil fertility and sustainable Agriculture: Current issues and future challenges. Washington D.C. International Food Policy Research Institute. Food, Agriculture and Environment Discussion Paper., pp: 32.

[4] Khan, A., M.T. Jan, K.B. Marwat and M. Arif, 2008. Organic and Inorganic nitrogen treatments effects on plant and yield attributes of maize in a different tillage systems. Pak. J. Bot., 41(1): 99-108.

[5] Matsi, T.A., S. Lithourgidis and A.A. Gagianas, 2003. Effect of injected liquid cattle manure on growth and yield of winter wheat and soil characteristics. Agron. J., 95: 592-596.

[6] Ali, K., F. Munsif, M. Zubair, Z. Hussain, M. Shahid, I.U. Din and N. Khan, 2011. Management of organic and inorganic nitrogen for different maize varieties. Sarhad J. Agric., 27(4): 525-529.

[7] Gehl, R.J., J.P. Schnidt, L.D. Maddux and W.B. Gordon, 2005. Corn yield response to nitrogen rate and timing in sandy irrigated soil. Agron. J., 97: 12301238.

[8] Tolessa, D., G. Gemechu and L. Melakeselam, 1994. Response of Maize to Split Application of Nitrogen Fertilizer at Bako. Crop Sci. Society of Ethiopia., 6: 56-60.

[9] Bhardwaj, V., V. Yadav and B.S. Chuhan, 2010. Effect of nitrogen application timings and varieties on growth and yield of wheat grown on raised beds. Archives Agron. Soil Sci., 56(2): 211-222.

[10] Sitthaphanit, S., V. Limpinuntana, B. Toomsan, S. Panchaban and R.W. Bell, 2010. Growth and yield responses of maize to split and delayed fertilizer applications on sandy soils under high rainfall regimes. J. Nat. Sci., 44: 991-1003.

[11] Arif, M., M.T. Jan, M.J. Khan, M. Saeed, I. Munir, Ziauddin, H. Akbar, Shahenshah and M.Z. Khan, 2011. Effect of cropping system and residue management on maize. Pak. J. Bot., 43(2): 915-920.

[12] Steel, R.G.D. and J.H. Torrie, 1980. Principles and procedures of Statistics., $2^{\text {nd }}$ edition.

[13] Nasim, W., A. Ahmad, T. Khaliq, A. Wajid, M.F.H. Munis, H.J. Chaudhry, M.M. Maqbool, S. Ahmad and H.M. Hammad, 2012. Effect of organic and inorganic fertilizer on maize hybrids under agro-environmental conditions of Faisalabad-Pakistan. Afr. J. Agric. Res., 7(17): 2713-2719.

[14] Shah, S.T.H., M.S.I. Zamir, M. Waseem, A. Ali, M. Tahir and W.B. Khalid, 2009. Growth and yield response of maize (Zea mays L.) to organic and inorganic sources of nitrogen. Pak. J. life soc. sci., 7(2): 108-111.

[15] Sharma, R.N., 1980. Effect of planting techniques and time and method of fertilizer application on Maize. Indian J. Agron., $25: 555$.

[16] Mohsin, A.U., J. Ahmad, A.U.H. Ahmad, R.M. Ikram and K. Mubeen, 2012. Effect of nitrogen application through different combinations of urea and farm yard manure on the performance of spring maize. J. Anim. Plant Sci., 22(1): 195-198. 